\title{
POPULATION INCREASE IN NEW YORK STATE
}

\begin{abstract}
GOLLOWING up two previous studies of recent changes in the population of New York State, W. A. Anderson now examines the natural increase in that population (Cornell Univ. Agricultural Experiment Station, Bull. 733, 1940). 'Natural increase' is here measured through an index in which the number of children less than five years of age per 1,000 women aged 20-44 years is divided by a replacement ratio, this ratio being the number of children less than five years of age per 1,000 women, aged 20-44, in the stationary population which would result from the continual operation of the current mortalityrates and in the absence of any migration.

Replacement ratios as of 1930 have been computed by the Scripps Foundation for Research in Population Problems, as follows: New York State 442, Urban 443 , Rural 439 . Are the populations in the various areas of the State reproducing at these rates? New York State as a whole with an index of natural reproduction of 88 , which is 12 points below the necessary, is not reproducing itself, while it is decidedly deficient as compared with the native population of the United States as a whole, which is reproducing at the rate of 112 . The urban population of the State has an index of 84 (U.S.A. 86), but the index of the rural population is 120 (U.S.A. 154), that of the farm population being 139 and the nonfarm 113. Thus the urban population is not replacing its losses, and inasmuch as 87 per cent of the women of 20-44 reside in urban areas, the urban type of population influences the natural increase of the State most significantly, being about four times as important as the rural population in determining the total natural increase.

Several important social implications result from these facts: If the population remains constant or increases, migration both from without and within the State will be considerable. If mobility within the State increases, this normally being after adolescence, important issues as to the finance and adequacy of education arise, affecting also the standing of churches and other social organizations. The question whether the excess population is being produced by the class most fitted economically, socially, and educationally requires special study, though it has been suggested that it is derived from those least fitted to reproduce at the higher rates.
\end{abstract}

\section{FORTHCOMING EVENTS}

[Meeting marked with an asterisk is open to the public.]

\section{Monday, January 27}

Royac Society of Arts (at John Adam Street, Adelphi, London, W.C.2), at 1.45 p.m.-Sir David Chadwick: "Some Problems of World Economic Development" (Cantor Lectures, 2).

\section{Tuesday, January 28}

Royal Anthropological Institute (AND Members of the Royal Central Asian Society) (at 21 Bedford Square, London, W.C.1), at 2.30 p.m.-M. Q. E. Kastrati : "The Impact of Western Influences on Albanian Cultural Tradition".

Royal Institution (at 21 Albemarle Street, London, W.1), at 2.30 p.m.-Sir William Bragg, F.R.S.: "Diffraction".*
WARBURG INSTITUTE (at the Imperial Institute Buildings, London, S.W.7), at 2.30 p.m.-Miss Rachel Levy: "Relations between East and West among the Earliest Known Civilizations".

\section{Wednesday, January 29}

Royal Society of Arts (at John Adam Street, Adelphi, London, W.C.2), at 1.45 p.m.-Lt.-Col. F. C. Temple: "Municipal Manufacture of Humus from Habitation Wastes".

\section{Friday, January $3 I$}

North-East Coast Institution of Engineers and Shipruilders (in the Mining Institute, Newcastleupon-Tyne), at 6 p.m.-Mr. Alexander Kari : "Effect of some External Factors on the Performance of Single-Screw Ships".

\section{APPOINTMENTS VACANT}

APpLICATIONs are invited for the following appointments on or before the dates mentioned:

Lecturer in Mathematios at the North Staffordshire Technical College, Stoke-on-Trent-The Clerk to the Governors, Town Hall, Hanley, Stoke-on-Trent (February 1).

ChiEf Engin kering AssistanT-The Water Engineer and Manager, The Council House, Coventry (endorsed 'Chief Engineering Assistant') (February 3).

Assistant Lectorer in the Mechanical EngINeERING DepartMENT of the Coventry Technical College-The Director of Education, Council House, Coventry (February 7).

graduate assistant Teacher for Mechanical Engineming SuBJEOTS-The Principal, Acton Technical College, High Street, Acton, London, W.3 (February 10).

MAINTENANCE ENGINEER FOR THE TRANSPORT AND HARBOURS DEPARTMENT of the Government of British Guiana-The Crown Agents for the Colonies, 4 Millbank, London, S.W.1 (quoting M/9393).

\section{REPORTS AND OTHER PUBLICATIONS \\ (not included in the Monthly Books Supplement)}

\section{Great Britain and Ireland}

National Institute of Industrial Psychology. Annual Report and Statement of Accounts for the Year ended 30 September 1940. Pp. 20. (London: National Institute of Industrial Psychology.) [1912 University of Cambridge School of Agriculture Memoirs. Memoirs Nos. 11-12: A Brief Summary of the Papers published by the staffs of the School of Agriculture and its Associated Research Institutes during the period Oct. 1st, 1938-Sept. 30th, 1940. Pp. 41. (Cam. bridge : School of Agriculture.) $2 s$.

\section{Other Countries}

Cornell University : Agricultural Experiment Station. Bulletin 728: An Economic Study of Farming in Tompkins County, New York, 1937. By Philip A. Henderson. Pp. 65. Bulletin 729: Receipts and Expenditures of Rural New York Counties. By O. H. White. Pp. 75. Bulletin 730: Protein and Vitamin Supplements for Growing and Fattening Pigs. By John P. Williams and F. B. Morrison. Pp. 45. Bulletin 731 : Experiments with New Electric Devices for Pasteurizing Soils. By A. G. Newhall. Pp. 38. Bulletin 732: Handling and Shipping Lettuce in New York. By Hans Platenius. Pp. 24. Bulletin 733: Natural Increase in the Population of New York State. By W. A. Anderson. Pp. 22. Bulletin 735: An Analysis of Dealers' Sales of Milk and Cream in the New York Market, 1933-38. By Charles J. Blanford. Pp. 24. Bulletin 739: The Incubation Test as an Indication of the Keeping Quality of Butter. By H. B. Naylor and E. S. Guthrie, Pp. 19. Memoir 229; Forest-Site Quality Studies in the Adirondacks, 1: Tree Growth as related to Soil Morphology. By Roy L. Donabue. Pp. 44. Memoir 230: The Morphology of the Apple and other Pome Fruits. By L. H. MacDaniels. Pp. 32. Memoir 231: Analyzing Dats for Relationships. By F. A. Harper. Pp. 14. (Ithaca, N.Y.: Cornell
University.)

U.S. Department of the Interior: Office of Education. Bulletin 1937, No. 2: Biennial Survey of Education, 1934-1936. Vol. 1. Pp. 1937, No. 2: Biennial Survey of Education, 1934-1936. Vol. 1. Pp.
v $+602+6$. (Washington, D.C. : Government Printing Office.) [1912

The Story of Vitamin $\mathbf{B}_{1}$ (Thiamine Hydrochloride U.S.P.) Compiled by Dr. C. R. Addinall, Revised edition. Pp. 72. (Rahway,
N.J.: Merck and Company, Inc.) N.J. : Merck and Company, Inc.)
Smithsonian Miscellaneous Collections. Vol. 99, No. 7: A Systematic Classification for the Birds of the World. By Alexander Wetmore. (Publication 3592.) Pp. ii +12. (Washington, D.C.: Smithsonian Institution.) 